\title{
From Rules of Life to Rules of Law. An Account of M. Krygier Approach to Sociological Jurisprudence
}

\author{
Lidia Rodak ${ }^{1}$ \\ Published online: 5 November 2019 \\ (c) The Author(s) 2019
}

\begin{abstract}
This essay offers a personal reading of prof. Martin Krygier's scholarship. Linking the history of Krygier's family with his view on sociological jurisprudence, especially on the living law concept, I draw the connections between the personal narration of rules of life and rules of law. His scholarship can be interpreted as a development of the living law concept integrating personal narrations of living humans in living law institutions.
\end{abstract}

Keywords Living law $\cdot$ Sociological jurisprudence $\cdot$ Martin Krygier $\cdot$ Rules of law

"Law is an institution that swims in the ocean of social complexity" M.K.

\section{From Rule of Life to Rule of Law. Unpredictability}

I have never seen Martin Krygier alone. In the places where he is supposed to be alone, he is not. When standing in the centre, the place that by definition makes us naked, he speaks for many. He shares and connects us. When standing in the corner of the corridor accompanied by his shadow only, he is not alone either. After reading his Civil Passions, I have understood why. Martin Krygier is the son of Roma and Richard. His family, by standing behind him, gave him a background to become who he is. Taking the family lesson, he built the next floor of the common human foundations, from where he speaks as an academic. This is visible not only in the topics he works on and in his scholarship, but also in his approach

His parents, Polish Jews, left Poland in 1939 soon after they had married when the Nazis invaded the country. The long and turbulent exodus to save their lives that accidentally ended up in them settling in Australia expresses the unpredictability of the course of human life. The way in which they experienced the journey from

Lidia Rodak

lidia.rodak@us.edu.pl

1 Research Center for Women's Socio-Legal Studies, Faculty of Law and Administration, University of Silesia, Katowice, Poland 
Warsaw to Sydney was full of turns of actions directed by history, politics, law, personal virtues and the dark side of individuals. Martin Krygier recognizes his role as one of the protagonist of the family story in which he writes his own chapter, which starts in the belly of a grandmother and will be read by his grandchildren. Accepting the fate of the family which was basically thrown to Australia going through the ocean of unpredictability, he experienced the interconnections between the rules of life and rules of law. This experience teaches one how to be attentive, how to always keep one's eyes open to what is around us, and the heart open to feel the pain and loss. However, it is not only a lesson in life, but also a lesson in legal philosophy on the changeability and unpredictability of social forces which underpin legal systems.

The idea of living law was expressed by Ehrlich who compared the law to a river ${ }^{1}$ stressing the internal dynamism and strength of elements which are also particular to the law. However, the metaphor of a river is somehow narrow. Humans control rivers by regulating and channelling their flows. This reminds us of the approach to law in which legal regulations are treated instrumentally to reach planned aims by channelling social forces. The effectiveness of legal institutions is attained by the control over the social reality as saddling a wild horse. The power and the potency of law is built on this.

Krygier's approach goes one step further as he uses another metaphor stating that: Law is an institution that swims in the ocean of social complexity. ${ }^{2}$ Such a view of the concept of living law places it as one of many elements in the whole universe, and expresses the uncontrolled strength and unpredictability of social forces. Both metaphors use the property of living water to highlight its aspects of autonomy and independence from humans' control. However, the ocean as a metaphor for society in which legal institutions drift is more radical and more adequate to describe reality. The effectiveness of the law, as one of its essential features, is in collision with its tendency to drift in oceanic social forces, but denying its effectiveness is denying its power and significance.

This is the view of law which emphasizes its capacity to direct society, like a river, towards some specified, well-defined goals by using legal norms as instruments helping to achieve the goals. This view assumes that society will surrender to or obey these norms, and when this does not happen, law uses its force or coercion to make legal norms effective. However, many historical examples show that this scenario implies the presence of an arbitrary power to impose the rule of law on society, very often ignoring society's particularities and identity. In all these situations where legal regulations drift in their own direction in the ocean of unpredictability, there is only one solution for the legal system to be put back on track: force and arbitrary power.

\footnotetext{
${ }^{1}$ Ehrlich E (1936) Fundamental Principles of the Sociology of Law. Harvard University Press, Cambridge, MA.

${ }^{2}$ Lecture NED, What's the point of Rules of Law? https://www.ned.org/events/whats-the-point-of-therule-of-law/?fbclid=IwAR3GI6RXoUm-Xrdw8Vt0QTqSnUgXCyXrBMaYIaO_pFeiSPS1_gYD8B EZ1H0.
} 
The fact that law cannot be disconnected from the logic of power in order to be effective is not overlooked by Kryger's view on the rule of law. In fact, his political view is strongly present in his approach to the rule of law, as power underpinned the discourse on rules of law creating the possibility to effectiveness. However, Krygier stresses that power without sensitivity to social expectations, interests and the recognition of rights, becomes arbitrary.

\subsection{Putting Law in its Place. Complexity}

Krygier's way of thinking is very close to that of Selznick, a scholar who is very important to him, as both of them adopt an ecumenical approach integrating the political, moral, sociological, historical and legal perspectives. What they have in common is not only their style of work and topics of interests, but also an intellectual and moral sensitivity. As every very good student of a great master pushes things forward in his or her own way, so did Krygier: bravely and attentively.

In particular, Krygier considered Selznick's prophecy to be fulfilled, that the greatest contemporary challenge for the sociology of law is the postulate of the integration of jurisprudence and the sociology of law, at the price of both being relegated to the periphery. This might be one of the reasons why Krygier carried out the research on the topic of his life, "rules of law", with an ecumenical perspective. In applying such a holistic methodology, also adopted by Selznick, Krygier bravely limits the legal discourse to merely a technical narrative, putting law in its right place, against the current scholarship of legal philosophy. The effort of the last century scholarship, especially of analytical legal philosophers, results in the creation of a sophisticated discipline which became art for the sake of art, carrying out the very analysis of fundamental questions on the nature of the law.

Krygier, on the contrary, approaches the topic of "rules of law" perceiving them as a type of activity of living humans and living institutions under different ranges of limitations. Like Selznick, he sees law placed "IN" the society as its immanent integrative part, not solely the context for law. To better understand their interdependence it is better to talk about: "law within society", 3 embedded in its oceanic forces.

\section{Bringing Complexity Through Subjectivity}

Bringing the history of his family and making his style of writing personal is, in my view, very significant to explain the complexity of rule of law. When reading Krygier's "Civic values", especially the opening stories of this collection of essays on his mother Roma and his father Richard, I feel like a reader of a novel whose emotions are involved in the plot of a touching story. Feeling moved, I was well prepared to take a not-so-easy lesson on rules of law in the war and during cold war history.

${ }^{3}$ Krygier M (2012) Philip Selznick: Ideals in the world. Stanford University Press, Stanford. 
Writing authentically and with passion, including subjective personal narration, is probably the only way to express the social complexity. This is something that the legal discourse, with its simplifications, can barely touch upon. Also, the standards of the socio-legal discourse or any other scientific narration use generalisation as the strategy to provide an objective explanation and universal validity. Complexity cannot be successfully approached by the generalized discourse of theory.

Fully conscious of this, Krygier uses the personal narration to bring the reader from the life narrative to the theoretical problems of the rules of law. Also, his personal story has the value of what we can best profit from subjectivity: a deep insight and the possibility to see all shades of grey. As a reader feeling emotionally engaged, I am ready to experience intellectual catharsis, bringing my consciousness to an upper level, following the author who reassures by his constant presence. By reading Krygier I learn in a deep sense. I gain the experience from the life of a multidimensional protagonist, since my emotions are involved. I can see with my own eyes, feeling my own emotions and having my own perceptions. I feel so free to look through my own eyes, since there are no claims to any objective truth.

Explaining the ideas in the world by telling the stories of real-life people, Krygier takes these ideas to a higher level by showing the relationships between them, explaining their meaning and creating theory through generalization. This is so far from the intellectual journey through the analytical landscape ordering the definitions that gives us only more information. Bringing in the personal narrative not only makes the picture more adequate to reality, but also releases the potential of dialogue and relationships.

As a result, as a reader I receive a great deal of personal freedom to adopt my own interpretation and an invitation to engage in dialogue with the author, as he is he and I am I. For me, these are the highest academic standards not only of transparency and honesty as the author reveals himself showing that experience stands behind his knowledge. In doing so, he also gives the inspiration to sociology of law on how to include subjectivity into the legal discourse.

\subsection{Minotaur. New Reading}

This style of academic writing that seems very valuable to me goes beyond the standard dualism based on the post-Cartesian paradigm of doing science, the division of objectivity and subjectivity, and of the body and the mind.

I perceive the problem of both legal science and legal discourse as not being responsive to subjectivity, and displaying a lack of sensitivity to the personal rights of subjects who are objectified by the legal discourse. This problem, that could be called a lack of embodiment in law/by law, is challenged by Krygier's scholarship. In this undertaking, he can be compared to a Minotaur, the hybrid creature who stores the forgotten wisdom of the ancient labyrinth. The Minotaur ${ }^{4}$ illustrates the

\footnotetext{
4 According to a new reading of the myth of the Minotaur and the Labyrinth, it was known in times that preceded the Greeks (from Assyria and Persepolis), who only told stories about the Minotaur that were known well before then. See more, Eliade M (2014) History of Religious Ideas, Volume 1: From the Stone Age to the Eleusinian Mysteries, University of Chicago Press, Chicago.
} 
relationship between a human being and an animal representing the divine element as an effect of the multiplication of vital forces, a combination of human and divine forces. A man/a bull, a half god who had access to holy secrets and a holy place labyrinth.

The Minotaur used to live in a labyrinth which was a holy place, as it used to be a reservoir of grain that died in the soil and gave birth to new life. In this sense, the labyrinth takes a womb's figure and symbolizes a place similar to a granary, where food for our soul is stored. Entering the labyrinth and following its winding corridors where one cannot see what is next, one must go ahead as if one's eyes are closed, with the attention turned towards him/herself. This is the way to reach the goal, the holy centre of yourself - to turn the attention to the subjectivity. One can only successfully leave the labyrinth after meeting him/herself. By keeping yourself in the centre one can look at the external world. In this sense, the Minotaur is "the one that remembers" how it was before duality, when the body and mind were one. This is manifested by the presence of what is personal but embedded in every step that was taken.

In this sense Krygier reminds us of the wisdom of the Minotaur who lived in the labyrinth. Krygier is in contact with his centre, attentive to what is inside him and what is around him. And what is around him is the constantly changing world with living people boarded on the ship sailing the ocean. What Krygier did in his academic works represents the Minotaur who survived and left the labyrinth to start a new story, a personal turn in the sociological jurisprudence.

The separation of the law from society is just as artificial as the separation of body (subjectivity) and mind (objectivity). The philosophy of law/jurisprudence is based on dualistic assumptions that cut out the subject and its subjectivity from the discourse. In this sense, it is coherent with that of the traditional discourse of law, and does not attentively care about individuals and their rights. As a consequence, pluralism cannot be respected as part of the existing practice and legal tradition.

Being personally present in the discourse of jurisprudence that Krygier cultivates is coherent with the view that the law and society are parts of the same living organism. But in jurisprudence, we need the Minotaur who speaks the voice from his body, who draws from rooting in a locality and from the connection with emotions, ready to accept everything that can be brought about by the change: disintegration, pain and loss. That is the wisdom of accepting the past, and that is the condition of moral and intellectual fragility, both on the individual and collective level.

\section{The Therapist for Post-Communist Systems of Law}

Krygier put so much hope in my thinking about law, as a person brought up in the post-communist legal system who is again experiencing a degradation of rules of law in her own country. I assimilated rules of law and human lives as separate orders, often functioning side by side, that allows them to be violent.

Krygier is the best therapist for post-communist systems of law. I can see his mission as explaining that rules of law are embedded in the rules of life. He renews the living law concept, where law is perceived as a type of activity of living humans and 
living institutions under different ranges of limitations. This is an important lesson for jurisprudence in post-communist Europe and especially for Poland, where rules of law again appear as a challenge to democracy.

Open Access This article is distributed under the terms of the Creative Commons Attribution 4.0 International License (http://creativecommons.org/licenses/by/4.0/), which permits unrestricted use, distribution, and reproduction in any medium, provided you give appropriate credit to the original author(s) and the source, provide a link to the Creative Commons license, and indicate if changes were made.

Publisher's Note Springer Nature remains neutral with regard to jurisdictional claims in published maps and institutional affiliations. 